\title{
The Effect of the Pandemic on Character Education for Children in Schools
}

\author{
Wina Nurhayati Praja*, Pandu Hyangsewu \\ Indonesian education university, faculty of social science education, street Doctor Setiabudi 229, \\ Indonesia
}

\begin{abstract}
Research background: The background of this research is to find out the development of character education values during this covid-19 pandemic. Where during the COVID19 pandemic, the community was required to carry out online activities including the field of education, namely schools that were conducted online for school students. The method used by researchers in this study is by distributing online questionnaires with a total of 13 respondents who contributed. Character education has a focus on the process of instilling values, in the form of understandings, procedures for caring for and living these values, and how a student can have the opportunity to be able to practice these values in real terms. Of course, character education is very important for students in preparing their future in order to achieve their goals and to be applied in social life.

Purpose of the article: This research is motivated to determine the development of the value of character education during the Covid-19 pandemic. Where when the Covid-19 pandemic, the community was required to carry out activities online, including in the field of education, namely schools that were conducted online for school students.

Methods: The method used by researchers in this study is by distributing questionnaires online with a total of 13 respondents who contributed. Character education has a focus on the process of cultivating values, in the form of understandings, procedures for caring for and living these values, and how a student can have the opportunity to be able to practice these values in real terms.
\end{abstract}

Keywords: value, pandemic, education, student

JEL Classification: G10, G21

\footnotetext{
*Corresponding author: Wina Nurhayati Praja (winapraja@upi.edu)
} 


\section{Background}

COVID-19 or Corona Virus Disease has made the world community restless for the past two months. The cause of this corona outbreak is the Novel Coronavirus or SARS-Cov-2 (World Health Organization, 2020) quoted by (Yoga Purandina \& Astra Winaya, 2020). Previously, this type of disease had never been detected by experts in the medical world. This type of epidemic is indeed the first reported outbreak in a city in China, namely Wuhan. This type of virus can develop so quickly by infecting humans and animals through the respiratory system of these living things. As of April 2020, approximately 1.8 million people have been infected by this type of virus and around hundreds of thousands of these people are unable to survive the virus or some have died in 213 countries in the world (World Health Organization, 2020b) quoted by (Yoga Purandina \& Astra Winaya, 2020)

According to research, the incubation period for COVID-19 ranges from 1 to 14 days, and generally 3 to 7 days. Common symptoms that occur are fever, cough, and shortness of breath. While other symptoms such as congestion, runny nose, sore throat, myalgia, and diarrhea are rare. Symptoms and signs in severe cases are shortness of breath and/or hypoxaemia (usually occurs after one week inset), and in the worst cases can rapidly develop such as acute respiratory distress syndrome (ARDS), septicindant blockage, bleeding, multiple organ failure, and others. Most patients have a fairly good diagnosis based on this new diagnosis. As for the elderly and people with chronic diseases, generally have a poor prognosis. While cases in children generally have relatively mild symptoms.

The COVID-19 pandemic is a health crisis that has almost covered health problems throughout the world. Almost all countries decide to isolate schools, colleges and universities. Even the United Nations (UN) became so uncomfortable with this fact. The United Nations captures that the education sector is one of the sectors most affected by the corona virus. Worse yet, it happened quickly and on a wide scale. (Purwanto et al., 2020)

Public compliance with government regulations during this pandemic is one of the most decisive points. The government and the community must be able to help each other in overcoming the COVID19 pandemic. This shows the forms of cooperation and efforts that can be carried out in overcoming the COVID-19 pandemic. Therefore, it is an obligation for us to always comply with government regulations in an effort to deal with this COVID-19 pandemic. In Islam, the success of a group in one country is produced by their obedience to their leaders and scholars. (Abdusshomad, 2020)

Anwar Makarim issued Circular No. 4 of 2020 regarding the implementation of coronavirus disease education. While studying from home. The Minister of Education and Culture emphasized that online / distance learning is carried out to provide students with a close learning experience, without being burdened with data that complements the success of the curriculum for promotion or class promotion. The Minister of Education and Culture recommended that areas learning from home ensure teachers also teach from home, in order to maintain teacher safety.

Until recently, classes were regarded as real education by most Indonesians. People still think that classrooms are real schools and that online courses are less effective. People do not think that online courses can help educate children, even though there are many start-ups in online education. We think classroom closures have an impact on teachers, students and parents everywhere. If in the past many schools used technology in learning, then in this unusual situation, all schools in Indonesia are forced to use technology in the teaching and learning process. When distance learning has to be applied in education, when students have to study from home,

One of the famous teachings of Indonesian father Ki Hadjar Dewantar was: "Everyone becomes a teacher in every home and becomes a school." If we incorporate his teachings into the 2013 curriculum objectives, at least we will be able to take lessons. First, every elderly family member must teach spiritual attitudes, social knowledge, knowledge, and skills. Second, each house he uses is a place for each family 
member, especially children, to acquire spiritual attitudes, knowledge and skills for a meaningful life in the future.

E-learning is an electronic deep learning process. Its use can be accessed online (Weni and Isnani, 2016). Increase mastery Regarding learning materials, increasing interaction between students and educators and facilitating the learning process are the goals of e-learning in its application (Darmayanti et al., 2007). For effective use in future this Pandemic. But it is used less, because the content is only text or slides. Speak only, you need to develop it to increase interest in learning (Cucus and Aprilinda, 2016). E-Learning media using the whatapp application as a learning medium during a pandemic is considered effective because it is flexible and effective use anytime anywhere, it can improve learning. But in its use must use a good internet connection. When used, it must be adjusted to the level of learning and the quality of learning.

The word character comes from the Greek, namely charassein, which means to engrave which has a meaning in Indonesian, namely painting or drawing, like people who are painting paper, carving a stone/metal. Having a source from that understanding, character can be interpreted as a sign or characteristic that is specifically, and therefore can give birth to a view if character is 'a pattern of behavior that has individual characteristics, a moral state of a person' (Sudrajat, 2011) quoted by (Sudrajat, 2011) quoted by (Sudrajat, 2011). Abdusshomad, 2020)

The term can also be interpreted, character can be interpreted as basic human nature in general, humans have many traits that depend on environmental factors of life (Mu'in, 2011) quoted by (Abdusshomad, 2020). Character education is an education which are based on ethical values core rooted in a democratic society, such as respect, responsibility, trustworthiness, fairness and, of caring, honesty, and civic virtue and citizenship (Murphy, 1998) in the quotation by (Abdusshomad, 2020). Character education has a focus on the process of inculcating values, in the form of understandings, procedures for caring for and living these values, and how a student can have the opportunity to be able to practice these values in real terms (Susanti, 2013). Lickona also states that the meaning of character education is a deliberate effort to be able to help someone so that someone can understand, pay attention, and carry out true ethical values (Lickona, 1991).

Character education has the aim of developing the values that shape a nation's character in this case Pancasila, which includes: developing the potential of a student to become a human being who has a good heart, always thinks well, and behaves well; build a nation that has Pancasila; and can develop the potential of citizens to have self-confidence, be proud of their homeland and country and love all mankind (Kemendiknas, 2011). The purpose of this study was to obtain information about the effect of the COVID-19 pandemic on character education for children in schools using descriptive qualitative methods.

\section{Method}

To find out the data in more depth, the researchers here use qualitative methods. Qualitative Research Methods are used because they emphasize more on aspects of in-depth understanding of a problem. Qualitative research is research that will produce and process descriptive data. The basis of research used by researchers is a survey. The survey method will get data from a certain location, in this case the researcher will collect data by distributing online questionnaires to elementary school to high school students.

The researcher in this case chose to use the google form website to distribute the questionnaire to various schools by distributing the form through a link that was distributed to the subject easily. The time for this study was about 2 weeks. The population in this study were school children who had elementary to high school levels. While the sample is part of the population consisting of several respondents. 
The characteristics of the sample selection in this study are as follows:

1) Respondents are maximum 18 years old

2) Respondents are students who are still in school at the elementary to high school level

The data collection technique used by researchers in this case is by distributing questionnaires to students and school students. The questionnaire was conducted by giving a collection of written questions to the respondents and answered by the respondents directly on the form. The contents of the questionnaire are in the form of questions about character education topics such as honesty, discipline, independence, hard work, creativity, tolerance, responsibility, public speaking, love of nature, and so on. character education for school students and can make it easier to process data from the form.

\section{Results and Discussion}

Following the Regulation of the Minister of Education and Culture of Indonesia Number 4 of 2020 regarding distance learning to prevent the spread of the Covid-19 outbreak in Indonesia, learning requires collaboration between the roles of teachers, students and parents during the learning process. In addition, during the COVID-19 pandemic, the Government has a policy of implementing social distancing which causes all activities outside the home to be reduced and work is required to be done from home or often referred to as work from home. In terms of education, this pandemic period is a good opportunity for parents to be directly involved in the learning process of their children. The role of parents is so important for students in learning activities while at home in achieving the learning objectives to be achieved.

The research was carried out by giving a questionnaire/questionnaire to participants from elementary to high school students. Aspects that are assessed are the attitudes and behavior of students that reflect character values (values of responsibility, tolerance, love of reading, creative, and religious). Data collection with an online form instrument on the effect of the pandemic on character education for children in schools was carried out by 13 students. Where students provide answers to the statements on the form to themselves about attitudes and behavior according to the actual situation. The following are the results of research on the influence of the pandemic on character education for children in schools

1) Value of Responsibility Character

Ardianti (2017) states that a student can be instilled in the character of responsibility if he is accustomed to acting responsibly, especially to his environment. Regarding character formation, Furqon (2010:35) explains several ways to create character formation, namely by example, inculcating discipline, habituation, creating a conducive atmosphere, integration, and internalization. In more detail, Siburian (2012) explains that there are several indicators in instilling the character of responsibility, including (1) actions that should be done (2) planning what to do in the future, (3) always trying to do something, (4) doing things as well as possible. , (5) being able to control oneself towards something, (6) being able to apply good discipline, (7) thinking before doing something, (8) being able to be an example for everyone, and (9) being responsible for all words, attitudes, and behavior. action.

In the question about assessing the responsibility of students who have the statement "Learning at school online makes me more and more trying to always be trusted in words, actions, and work" the results of student answers are as shown in the image below: 
Belajar di sekolah secara daring membuat saya semakin mencoba agar selalu dapat dipercaya dalam perkataan, tindakan, dan pekerjaan

13 responses

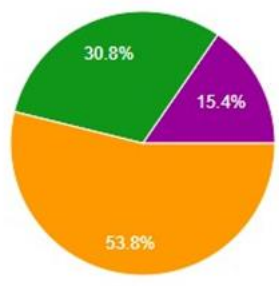

Sangat Tidak Setuju

Tidak Setuju

Biasa Saja

- Setuju

- Sangat Setuju

It was found that most of the respondents' scores were included in the "agree" category, which consisted of $30.8 \%$ agree and $15.4 \%$ strongly agree even though there were $53.8 \%$ of respondents who considered it normal, but here there were no respondents who responded neither agree nor strongly disagree. agree, so it can be concluded that the overall value of responsibility that students have while participating in online learning activities in class can make students more responsible for the behavior they do as much as $46.2 \%$ of students and as many as $53.8 \%$ of students feel normal with character education in terms of responsibility obtained from this online learning.

2) Value of Religious Character

Religious character is an attitude or behavior that is close to spiritual matters, obediently carrying out the teachings of the religion he adheres to. Through reflection on life experiences, a person can realize, understand, and accept his limitations so as to build gratitude to God the giver of life, respect for others, and the natural environment (Ivonna, 2013:17). Teachers have 2 (two) important roles, namely teaching and educating. These two tasks always accompany the teacher's steps both when carrying out duties and outside of assignments (teaching). Teaching is the task of helping and training students in understanding something and developing knowledge. While educating is encouraging and guiding students to progress towards full maturity. Maturity which includes intellectual, emotional, social, physical, spiritual arts, and moral maturity.

In the question about assessing the religious level of students who have the statement "Learning at school online makes me more obedient in carrying out religious teachings" the results of students' answers are as shown in the image below:

Belajar di sekolah secara daring membuat saya semakin patuh dalam melaksanakan ajaran agama

13 responses

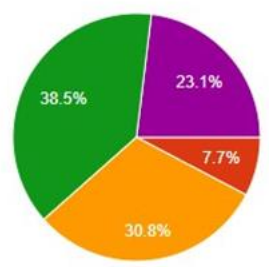

Sangat Tidak Setuju

Tidak Setuju

Biasa Saja

Setuju

- Sangat Setuju 
It was found that most of the respondents' scores were included in the "agree" category, which consisted of $38.5 \%$ agree and $23.1 \%$ strongly agree even though there were $30.8 \%$ of respondents who considered it normal and $7.7 \%$ did not agree which might be due to there are one or two factors that cause these students to feel less obedient in carrying out religious teachings due to online learning, so it can be concluded that overall the religious values that students have while participating in learning activities in online classes can make students more religious with character education in terms of the responsibility obtained from this online learning, but there could be internal and external factors from the student that caused the student's not to increase compliance in carrying out the religious teachings of students so that it was found that there were those who did not agree with the statement.

3) Character Values Like to read

The era of globalization as it is today demands high quality human resources. Improving the quality of human resources is an absolute prerequisite for achieving development goals. One of the vehicles to improve the quality of human resources is reading. Reads spoken what is written. Writing is an important aspect of reading because without writing a person cannot be said to be reading. The writing can be in the form of a word consisting of several letters, a sentence consisting of several words or a paragraph. Humans who are creative, intelligent and critical make reading a necessity in communicating.

In the question about assessing the level of reading pleasure of students who have the statement "Learning at school online makes me more diligent in reading books" the results of students' answers are as shown in the image below:

Belajar di sekolah secara daring membuat saya semakin rajin untuk membaca buku

13 responses
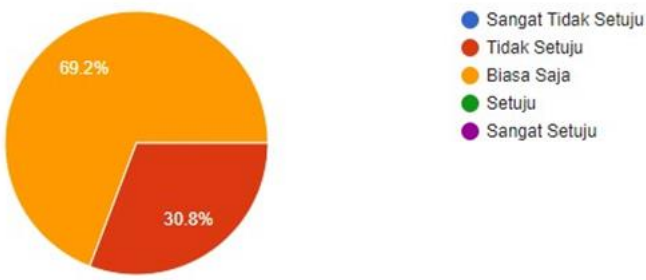

It was found that most of the respondents' scores were included in the "ordinary" category, which consisted of $69.2 \%$ mediocre and $30.8 \%$ disagreed. In this case the answer from the respondent this time has an answer towards disagreeing because there are as many as $30.8 \%$ of students who do not agree with the statement that they are more diligent in reading books, here the author concludes that maybe it is "normal" here for students as usual not reading books or reading books. it's normal to often read books depending on the habits of the students themselves, so that when online learning activities occur, most students are not affected to be more diligent in reading books, namely $69.2 \%$, but there are students who feel they are not more diligent in reading books, namely $30,8 \%$.

4) Tolerance Character Value

Tolerance is a character that is able to support the creation of harmony. The form of tolerance is in the form of respect for differences in ethnicity, religion, race, language, between religious groups, gender, and even different opinions. In elementary school, the character of tolerance is one of the important characters to be instilled. The character of tolerance is able to create awareness and acceptance 
of diversity in life so that harmony is realized among others in the midst of differences. At the age of school students, students begin to realize the appearance and differences in themselves and others. This awareness will raise questions for students when they know something different from someone so it is necessary to teach that everyone has differences and instill a way of appreciating these differences (Divine, 2013: 118).

In the question about assessing the tolerance level of students who have the statement "Learning at school online makes me more appreciative of differences in religion, ethnicity, ethnicity, opinions, attitudes, and actions of different people" the results of student answers are as shown in the image below:

Belajar di sekolah secara daring membuat saya semakin menghargai perbedaan agama,

suku, etnis, pendapat, sikap, dan tindakan orang lain yang berbeda

13 responses

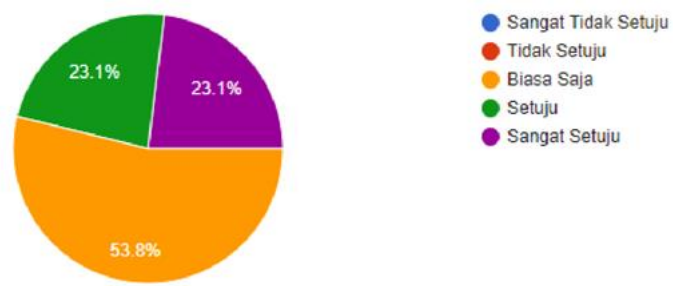

It was found that most of the respondents' scores were included in the "agree" category, which consisted of $23.1 \%$ agree and $23.1 \%$ strongly agree even though there were $53.8 \%$ of respondents who considered it normal but here there were no respondents who responded neither agree nor strongly disagree. agree, so it can be concluded that the overall value of tolerance that students have while participating in online learning activities in class can make students more tolerant of differences in religion, ethnicity, ethnicity, opinions, attitudes, and actions of others who are different as much as $46.2 \%$ of students and as many as $53.8 \%$ of students feel normal with character education in terms of tolerance obtained from this online learning.

5) Creative Character Value

Creativity is the path to the ability to think creatively. If someone has high creativity, then it shows that he has the ability to think creatively. According to Mardianto, creativity is a product of good and right ways of thinking (Mardianto, 2012) cited by (Panjaitan \& Surya, 2017). Meanwhile, according to Munandar (1999) quoted by (Panjaitan \& Surya, 2017) reveals that creativity is a general ability to create something new, because of the ability to provide new ideas that can be applied to problem solving, and as the ability to know the relationship between elements. which have existed.

In the question about assessing the level of creativity of students who have the statement "Learning at school online makes me more creative in solving problems at school and at home" the results of students' answers are as shown in the image below: 

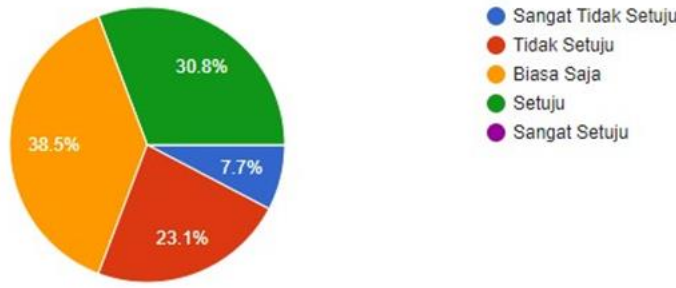

It was found that $7.7 \%$ of students strongly disagreed, $23.1 \%$ of students disagreed, $30.8 \%$ of students agreed, and $38.5 \%$ of students were average. This is balanced between students who agree with disagree that is a total of $30.8 \%$. So it can be concluded that the overall value of the creative character possessed by students while participating in online learning activities in class there are students who get to be more creative but some are not. Here the author concludes that there are many factors that can make these students more creative or not, namely internal factors and external factors that exist in the environment where students carry out online learning activities. So that the value of the creative character of students returns to the students themselves who determine it.

\section{Conclusion}

The Covid-19 pandemic has greatly affected habits and character education in society. Almost all learning activities around the world become online learning for students and students, including in Indonesia, which has a lot of impact on character changes in society. Character formation becomes an important value in society which over time can become a habit if the cultivation of character values is carried out repeatedly and routinely until it becomes a habit, and in the end it will not only become a habit but will become a character value. The parents and family of the self will certainly have an effective impact on the development of character values in children. In the current Covid-19 pandemic, collaboration is also needed between the role of teachers, families and the surrounding community in developing character values in children. The family certainly has an important role in supervising and guiding lovingly, firmly, and carefully for students to live life during this pandemic.

In this study, we obtained data that the character values that developed in students during the Covid19 pandemic were (1) the value of the character of responsibility, (2) the value of the religious character, and (3) the value of the character of tolerance. However, there are character values that do not develop or decrease, namely the value of reading or literacy characters and there is also a balanced character value, there are students who are developing and some are not developing, namely the value of creative characters. Judging from the development of these character values, of course changes in the development of student character values are positive and some are negative. Of course, the success of developing character values in children during the Covid-19 pandemic cannot be separated from the role of teachers and parents who are ready to transform from offline learning to online learning to be used as role models for applying good character to yourself. However, for the problems faced in the form of reading or literacy and creative character values, of course, it still needs to be considered so that students become more enthusiastic to practice their creativity and are more diligent in reading books to increase knowledge online or through their personal books. This is the 
momentum of character education in the family environment that we must pay attention to. I hope that until the COVID-19 pandemic ends, the pattern of character education in this family environment will continue continuously.

\section{Reference}

1. Abdusshomad, A. (2020). The Effect of Covid-19 on the Implementation of Character Education and Islamic Education.

2. QALAMUNA: Journal of Education, Social and Religion , 12 (2), 107115. https://doi.org/10.37680/qalamuna.v12i2.407

3. Arsanti, M. (2018). Development of teaching materials for creative writing courses containing religious character education values for students of PBSI, FKIP, UNISSULA study programs. KREDO: Scientific Journal of Language and Literature, 1(2), 69-88.

4. Hariandi, A., \& Irawan, Y. (2016). The Role of Teachers in Instilling Religious Character Values in the School Environment in Elementary School Students. Gentala Journal of Basic Education, 1(1), 176-189.

5. Julandi, GI (2018). School Efforts to Grow Students' Love of Reading Character at SMK Negeri 1 Sidoarjo. Moral and Citizenship Studies, 6(2).

6. Ministry of National Education. (2011). Character Education Guide. Jakarta: Center for Curriculum and Books of the Ministry of National Education.

7. Lickona, T. (1991). Educating for character: How our schools can teach respect and responsibility. New York: Bantam Books.

8. Mulvey, C. (1984). Wage Policy and Wage Determination in 1983. Journal of Industrial Relations , 26 (1), 112-119. https://doi.org/10.1177/002218568402600108

9. Panjaitan, AH, \& Surya, E. (2017). Creative Thinking ( Creative Thinking ) in Learning . December, 5-8.

10. Purnamasari, YM, \& Wuryandani, W. (2019). Folklore-Based Big Book Learning Media to Improve Tolerance Characters in Early Childhood. Journal of Obsession: Journal of Early Childhood Education, 4(1), 90-99.

11. Purwanto, A., Pramono, R., Asbari, M., Santoso, PB, Wijayanti, LM, Choi, CH, \& Putri, RS (2020). Exploratory Study of the Impact of the COVID-19 Pandemic on the Online Learning Process in Elementary Schools. EduPsyCouns: Journal of Education, Psychology and Counseling , 2 (1), 1-12. https://ummaspul.ejournal.id/Edupsycouns/article/view/397

12. Sari, IP, \& Syamsi, K. (2015). Development of thematic-integrative textbooks based on the character values of discipline and responsibility in elementary schools. Prima Edukasia Journal, 3(1), 73-83.

13. Susanti, R. (2013). Application of Character Education Among Students. Journal of Al-Ta'lim, 1(6), 480-487. https://doi.org/10.37092/ej.v1i1.89

14. Yoga Purandina, IP, \& Astra Winaya, IM (2020). Character Education in the Family Environment During Distance Learning During the COVID-19 Pandemic. Cetta: Journal of Educational Sciences , 3 (2), 270-290. https://doi.org/10.37329/cetta.v3i2.454 